CZASOPISMO INŻYNIERII LĄDOWEJ, ŚRODOWISKA I ARCHITEKTURY JOURNAL OF CIVIL ENGINEERING, ENVIRONMENT AND ARCHITECTURE

JCEEA, t. XXXII, z. 62 (3/I/15), lipiec-wrzesień 2015, s. 447-456

\author{
Paweł SUCHORAB ${ }^{1}$ \\ Małgorzata IWANEK ${ }^{2}$ \\ Anna GLOWACKA ${ }^{3}$
}

\title{
OCENA EFEKTYWNOŚCI EKONOMICZNEJ WYBRANYCH SYSTEMÓW KANALIZACJI SANITARNEJ
}

\begin{abstract}
Poziom sanitacji obszarów wiejskich ulega w ostatnich latach znacznej poprawie. Związane jest to ze wzrostem inwestycji w zbiorcze systemy kanalizacyjne. Jednakże, w warunkach polskich, tereny wiejskie charakteryzują się nizinnym ukształtowaniem i rozproszona zabudową. Warunki takie nie sprzyjają budowie tradycyjnej kanalizacji grawitacyjnej, co powoduje konieczność stosowania systemów niekonwencjonalnych. Przed realizacją wybranego systemu, każda inwestycja powinna być poddana ocenie efektywności ekonomicznej celem określenia jej opłacalności finansowej. Ponadto, w ocenie należy uwzględnić także czynniki nieekonomiczne, jak podniesienie standardu życia. Do metod oceny projektów inwestycyjnych zalicza się metody statyczne i dynamiczne. W niniejszym artykule przedstawiono przykład analizy ekonomicznej inwestycyjno-eksploatacyjnej wybranych rodzajów kanalizacji sanitarnej dla wiejskiej jednostki osadniczej. Przeanalizowano rozwiązania grawitacyjnego, ciśnieniowego oraz podciśnieniowego odprowadzania ścieków bytowych. Trasy poszczególnych projektowanych sieci kanalizacyjnych były analogiczne, z uwzględnieniem rozwiązań charakterystycznych dla danych systemów. W ocenie pominięto budowę przykanalików od budynków, jako odcinków jednakowych we wszystkich analizowanych rozwiązaniach. Ocenę efektywności ekonomicznej przeprowadzono w oparciu o dyskontowe (dynamiczne) metody oceny projektów inwestycyjnych: dynamiczny koszt jednostkowy $D G C$, wskaźnik zaktualizowanej wartości netto $N P V$ oraz współczynnik korzyści i kosztów $B C R$. Zastosowane wskaźniki oceny projektów uwzględniały koszty inwestycyjne oraz, często pomijane, koszty eksploatacyjne. Na podstawie przeprowadzonej analizy ekonomicznej określono opłacalność realizacji każdego z rozpatrywanych systemów kanalizacyjnych, zasugerowano alternatywne do proponowanych rozwiązania oraz wskazano dalsze kierunki oceny projektów inwestycyjnych.
\end{abstract}

Słowa kluczowe: analiza ekonomiczna, metody dyskontowe oceny projektów, kanalizacja sanitarna, sanitacja wsi

\footnotetext{
${ }^{1}$ Autor do korespondencji/corresponding author: Paweł Suchorab, Politechnika Lubelska, ul. Nadbystrzycka 40B, 20-618 Lublin, tel. 81 5384139, p.suchorab@ wis.pol.lublin.pl,

2 Małgorzata Iwanek, Politechnika Lubelska, ul. Nadbystrzycka 40B, 20-618 Lublin, tel. 81 5384139, M.Iwanek@wis.pol.lublin.pl

3 Anna Głowacka, absolwent, Politechnika Lubelska
} 


\section{Wprowadzenie}

W ostatnich latach poziom sanitacji obszarów wiejskich ulega wyraźnej poprawie [9], szczególnie poprzez szybki wzrost inwestycji w zbiorcze systemy kanalizacji sanitarnej [11]. Według danych przedstawionych przez Główny Urząd Statystyczny, na przestrzeni lat 2007-2013 długość sieci kanalizacyjnych w obszarach wiejskich uległa ponad półtorakrotnemu zwiększeniu. Nadal jednak do systemów kanalizacyjnych podłączonych jest jedynie 31\% mieszkańców wsi [7], co świadczy, że poziom skanalizowania obszarów wiejskich wciąż jest niewystarczający [25]. Skutkuje to nieatrakcyjnością tych obszarów pod względem lokalizacji nowych inwestycji, zasiedlania oraz rozwoju [12], a także stopuje bardzo ważny dla tych rejonów rozwój rolnictwa i gospodarki żywieniowej [10].

Jedną z trudności związanych z przeprowadzeniem dalszej sanitacji wsi są znaczne nakłady finansowe związane $\mathrm{z}$ budową sieci kanalizacyjnej i oczyszczalni ścieków. Duże koszty tych inwestycji powodowane są uwarunkowaniami geograficzno-przyrodniczymi Polski, tj. nizinnym charakterem obszarów, wysokim poziomem wód gruntowych [2] oraz rozproszoną zabudową na terenach wiejskich [22]. Brak uniwersalnego modelu kanalizacji powoduje, że każdy obszar wymaga indywidualnego rozwiązania $\mathrm{z}$ uwagi na swoją różnorodność w ukształtowaniu terenu i warunki demograficzne. Częstym błędem podejmowanym na etapie projektowania jest próba realizacji sieci kanalizacyjnej jako sieci grawitacyjnej, nawet w terenie o wyjątkowo niekorzystnym ukształtowaniu wysokościowym [13]. Zazwyczaj skutkuje to dużo wyższymi kosztami wykonania sieci w porównaniu do innych wariantów. Dlatego, każdorazowa decyzja o wyborze danego systemu kanalizacyjnego, powinna być poparta analizą ekonomiczną, która może stanowić kompleksowy materiał dla oceny celowości podjęcia rozpatrywanych działań [5] i dzięki której możliwe będzie wybranie wariantu inwestycyjnie i eksploatacyjnie najkorzystniejszego [13].

Gmina, jako jednostka administracyjna odpowiedzialna za zbiorowe odprowadzanie ścieków [24], ponosi główne koszty inwestycyjne związane z budową sieci kanalizacyjnej [25]. Szansa pozyskania przez gminy zasobów finansowych z funduszy unijnych [11] otwiera możliwość przeprowadzenia działań poprawiających stan środowiska naturalnego, jednakże wysokość środków własnych lub skala dotacji nie mogą być jedynym wyznacznikiem decyzji o budowie sieci kanalizacyjnej. W aspekcie ekonomicznym należy kierować się przede wszystkim kosztami eksploatacji [8]. Decyzje podejmowane w odniesieniu do infrastruktury kanalizacyjnej często bowiem nie uwzględniają realiów ekonomicznych inwestycji, co w efekcie wpływa na funkcjonowanie przedsiębiorstw komunalnych. Komercjalizacja publicznych wodociągów i kanalizacji powoduje, że finansowe konsekwencje podjętych decyzji ostatecznie obciążają odbiorcę usług [21]. By ograniczyć trudności doświadczane na etapie eksploatacji, zaleca się przeprowadzenie kompleksowej analizy planowanej inwestycji. Ponadto, ocena zasadności budowy sieci kanalizacyjnej powinna uwzględniać nie tylko 
czynnik finansowej opłacalności, lecz także aspekty społeczne (np. zwiększenie komfortu życia).

Stosowane obecnie metody oceny projektów inwestycyjnych pozwalają gminom na określenie, czy realizacja planowanej inwestycji będzie ekonomicznie opłacalna lub który z rozważanych wariantów inwestycji cechuje największa opłacalność [23]. Uwzględniając czynnik czasu, metody te można podzielić na statyczne, nie biorące pod uwagę zmiennej wartości pieniądza w czasie, oraz na metody dyskontowe (złożone, dynamiczne), które ją uwzględniają [18]. Metody statyczne stosuje się najczęściej do wstępnej selekcji projektów, dla inwestycji typowych lub charakteryzujących się niewielkimi nakładami. Metody dynamiczne pozwalają objąć oceną cały okres funkcjonowania przedsięwzięcia (jego realizacji i eksploatacji) [23]. Do metod statycznych zalicza się: księgową stopę zwrotu, okres zwrotu oraz metody porównywania kosztów i zysków $[6,18]$. Wśród metod dyskontowych rozróżnia się m.in.: dynamiczny koszt jednostkowy $D G C$, zaktualizowaną wartość netto $N P V$ oraz współczynnik korzyści i kosztów $B C R[15,19,23]$.

W niniejszym artykule przedstawiono ocenę efektywności ekonomicznej wybranych systemów kanalizacji sanitarnej dla wiejskiej jednostki osadniczej, przeprowadzoną w oparciu o metody dynamiczne.

\section{Obiekt badań}

Miejscowość, dla której wykonano analizę ekonomiczną inwestycyjnoeksploatacyjną wybranych systemów kanalizacyjnych, ma charakter wiejski i zlokalizowana jest $\mathrm{w}$ województwie mazowieckim. Położona jest $\mathrm{w}$ terenie płaskim, lekko pofalowanym, z niewielkimi spadkami. W miarę zwarta zabudowa skoncentrowana jest wzdłuż dróg. Obszar planowanej inwestycji obejmuje grunty piaszczysto-gliniaste.

W ramach przeprowadzonej analizy rozpatrywano trzy, potencjalnie możliwe do realizacji, systemy kanalizacji sanitarnej. Były to tradycyjna grawitacyjna kanalizacja sanitarna z jedną pompownią ścieków oraz dwa systemy niekonwencjonalne: kanalizacja ciśnieniowa oraz podciśnieniowa. W celu uproszczenia analizy ekonomicznej założono jednakowe trasy głównych przewodów kanalizacyjnych, niezależnie od przyjętego rozwiązania projektowego - drobne różnice w sumarycznej długości przewodów wynikały z indywidualnego charakteru każdego systemu kanalizacyjnego. Dodatkowo przyjęto lokalizację studzienek przydomowych, przydomowych przepompowni ścieków lub studzienek z zaworem opróżniającym w miejscach istniejących zbiorników bezodpływowych. Założenie to pozwoliło na pominięcie w kalkulacjach 152 przykanalików wykonanych z rur PVC-U $160 \mathrm{~mm}$ - jako odcinków istniejących i jednakowych dla wszystkich wariantów. Obliczona średnia dobowa ilość dopływających do sieci ścieków wynosiła $41,4 \mathrm{~m}^{3} / \mathrm{d}$. 
W ramach pierwszego wariantu projektu koncepcyjnego, zaproponowano grawitacyjny system odprowadzania ścieków składający się z przewodów z PVC-U o średnicach $160 \mathrm{~mm}$ (przyłącza kanalizacyjne) oraz $200 \mathrm{~mm}$ (przewody sieciowe) o łącznej długości $8315 \mathrm{~m}$. Uzbrojenie sieci przewidziano $\mathrm{w}$ formie prefabrykowanych studzienek połączeniowych, przelotowych i rewizyjnych, wykonanych z tworzywa sztucznego (425 sztuk) lub betonu (14 sztuk). Celem odprowadzenia ścieków bytowych do gminnej oczyszczalni ścieków zaprojektowano strefową przepompownię ścieków DN1200. Ścieki tłoczone są do oczyszczalni rurociągiem tłocznym PE-HD o średnicy $90 \mathrm{~mm}$ o długości $200 \mathrm{~m}$. Sterowanie pracą pomp założono w sposób w pełni zautomatyzowany.

Drugim rozpatrywanym systemem zbiorczej kanalizacji sanitarnej był system kanalizacji ciśnieniowej. W ramach koncepcyjnego projektu przewidziano system odprowadzania ścieków składający się z układu przewodów z rur PE-HD

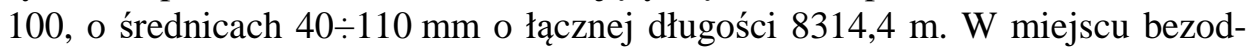
pływowych zbiorników ścieków przewidziano indywidualne przepompownie 152 sztuki. Uwzględnienie w przepompowniach kompletnego układu sterowniczego zapewnia ich bezobsługową pracę. Na sieci przewidziano również 5 studzienek z zaworami odpowietrzająco-napowietrzającymi.

Trzecim opracowanym rozwiązaniem $w$ ramach projektu koncepcyjnego był układ kanalizacyjnej sieci podciśnieniowej. W skład układu przewodów wchodził: kolektor podciśnieniowy $\mathrm{z}$ rur PE-HD 80 (zakres średnic $110 \div 160 \mathrm{~mm}$ ), podciśnieniowe przyłącza kanalizacyjne z rur PE-HD 80 (średnica DN90) oraz przewód ciśnieniowy z rur PE-HD 100 wraz ze stacją ssącotłoczącą. Łączna długość przewodów sieciowych: $8415 \mathrm{~m}$. Uzbrojenie sieci podciśnieniowej stanowiło 152 żelbetowych studzienek zbiorczych z zaworami opróżniającymi.

\section{Metodyka badań}

Spośród dostępnych metod oceny projektów wykorzystano metody dynamiczne (dyskontowe) jako najbardziej precyzyjne narzędzia oceny opłacalności przedsięwzięć inwestycyjnych. Analizę oparto o obliczenia wskaźników: dynamicznego kosztu jednostkowego $(D G C)$, wartości zaktualizowanej netto (NPV) oraz współczynnika efektów i nakładów $(B C R)$.

Dynamiczny koszt jednostkowy $D G C$ (ang. Dynamic Generation Cost) określa zdyskontowany koszt uzyskania wybranej jednostki rezultatu projektu (efektu społecznego lub ekologicznego) [15, 19]. W odniesieniu do gospodarki ściekowej, gdzie za miarę efektu (ekologicznego) można uznać ilość oczyszczonych ścieków, wskaźnik $D G C$ wyrażany jest w zł $/ \mathrm{m}^{3}$ [19]. Metoda dynamicznego kosztu jednostkowego jest w szczególności rekomendowana do oceny projektów związanych z ochroną środowiska [15]. Traktując społeczeństwo jako inwestora wspierającego rozpatrywane projekty o jednorodnym efekcie ekologicznym (np. budowa sieci kanalizacyjnej), uznaje się, że najkorzystniejszym jest 
projekt, który przy jednakowej kwocie przyniesie największy, łączny efekt ekologiczny (gdy $D G C$ projektu jest najniższe) [19]. Wartość dynamicznego kosztu jednostkowego określa się według formuły (1) [15, 25]. Formuła (1) jest prawdziwa, gdy czas analizy jest równy czasowi życia inwestycji, tj. główne składniki analizy całkowicie zużyją się w przyjętym okresie [20].

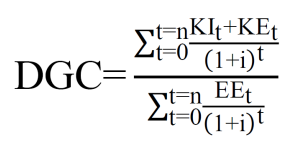

gdzie: $D G C$ - dynamiczny koszt jednostkowy, $\mathrm{z} t / \mathrm{m}^{3}$;

$K I_{t}$ - nakłady inwestycyjne w danym roku, zł;

$K E_{t}$ - koszty eksploatacyjne (bez amortyzacji) w danym roku, zł;

$E E_{t}-$ wskaźnik rezultatu (efektu) w danym roku, $\mathrm{m}^{3} /$ rok;

$i$ - stopa dyskontowa, \%;

$t$ - kolejny rok okresu obliczeniowego, rok;

$m$ - liczba lat okresu obliczeniowego, obejmująca czas budowy i eksploatacji, lata.

Drugim kryterium do przeprowadzenia analizy ekonomicznej inwestycyjno-eksploatacyjnej był wskaźnik wartości zaktualizowanej netto $N P V$ (ang. Net Present Value), który określa się poprzez porównanie ze sobą poniesionych nakładów z wartością bieżącą przyszłych przychodów z inwestycji, przy stałym poziomie stopy dyskontowej $[4,14,19,23]$. Inwestycja określana jest jako efektywna finansowo, gdy wartość $N P V$ jest dodatnia, czyli suma teraźniejszych (zdyskontowanych) wartości wszystkich przepływów pieniężnych netto z inwestycji jest większa niż wartość poniesionych przez inwestora nakładów [19]. W przypadku wielowariantowej analizy inwestycji, najbardziej opłacalny jest wariant o największej wartości wskaźnika $N P V$. Wartość wskaźnika $N P V$ można określić z zależności zapisanej w postaci (2) [25]:

$$
\mathrm{NPV}=\sum_{\mathrm{t}=0}^{\mathrm{m}} \frac{1}{(1+\mathrm{i})^{\mathrm{t}}}\left(\mathrm{W}_{\mathrm{t}}-\mathrm{K}_{\mathrm{et}}-\mathrm{J}_{\mathrm{t}}\right)
$$

gdzie: $N P V$ - wartość zaktualizowana netto danego przedsięwzięcia, zł;

$W_{t}$ - przewidywana w kolejnym roku (t) wartość efektu użytkowego, $\mathrm{zz} / \mathrm{rok}$;

$K_{e t}$ - przewidywane w kolejnym roku (t) koszty eksploatacji (bez amortyzacji), zł/rok;

$J_{t}-$ przewidywane w kolejnym roku (t) nakłady inwestycyjne, zł/rok.

Pozostałe oznaczenia jak we wzorze (1).

Ostatnią zastosowaną metodą oceny projektów do przeprowadzenia analizy ekonomicznej inwestycyjno-eksploatacyjnej była metoda wykorzystująca 
współczynnik efektów i nakładów BCR (ang. Benefit - Cost Ratio) [3, 17]. Wskaźnik ten określany jest jako stosunek zdyskontowanych wartości przychodów do zdyskontowanych wartości kosztów eksploatacji i nakładów inwestycyjnych z całego okresu trwania inwestycji. Uznaje się, że inwestycja jest efektywna, jeżeli wskaźnik $B C R$ jest większy lub równy 1, co oznacza, że wartość korzyści przekracza wartość kosztów inwestycji [20]. Wartość współczynnika $B C R$ można obliczyć wykorzystując formułę (3) [21].

$$
\mathrm{BCR}=\frac{\sum_{\mathrm{t}=0}^{\mathrm{m}} \frac{1}{(1+\mathrm{i})} \cdot \mathrm{W}_{\mathrm{t}}}{\sum_{\mathrm{t}=0}^{\mathrm{m}} \frac{1}{(1+\mathrm{i})^{\mathrm{t}}} \cdot\left(\mathrm{J}_{\mathrm{t}}+\mathrm{K}_{\mathrm{et}}\right)}
$$

gdzie: $B C R$ - wartość współczynnika efektów i nakładów, -; Pozostałe oznaczenia jak we wzorze (1).

Wykorzystując podane metody oceny projektów inwestycyjnych, wykonano analizę inwestycyjno-eksploatacyjną rozpatrywanych systemów kanalizacyjnych, bazując na wykonanych projektach koncepcyjnych, kosztorysach wstępnych proponowanych rozwiązań oraz oszacowanych na podstawie danych z Urzędu Gminy kosztach eksploatacyjnych. Wstępne kosztorysy inwestorskie poszczególnych wariantów uwzględniały koszty wykonania sieci kanalizacyjnych, koszty podłączenia instalacji elektrycznych dla przepompowni strefowej i stacji próżniowo-tłocznej oraz podłączenie do sieci energetycznej przydomowych przepompowni. Koszty eksploatacyjne obejmowały koszty energii elektrycznej, obsługi sieci, koszty osobowe i amortyzację. Oszacowania kosztów inwestycyjnych i eksploatacyjnych dokonano na poziomie cen z 2013 roku. Do obliczeń przyjęto następujące założenia:

- horyzont czasowy: 30 lat

- stopa dyskontowa i: $5 \%$

- miara rezultatu - ilość odprowadzanych ścieków: ... $15120 \mathrm{~m}^{3} / \mathrm{rok}$

- opłata za $1 \mathrm{~m}^{3}$ odprowadzanych ścieków: $3,19 \mathrm{zł}$

- opłata abonamentowa od 1 przyłącza: $8 \mathrm{zl}$

Szczegółowe koszty inwestycyjne i eksploatacyjne (bez amortyzacji) analizowanych rozwiązań przedstawiono w tabeli 1 . Najwyższe koszty inwestycyjne wykazał system kanalizacji grawitacyjnej, przy jednocześnie najniższych kosztach eksploatacyjnych. Najwyższe koszty eksploatacyjne uzyskano w kanalizacji podciśnieniowej, podczas gdy koszty inwestycyjne tego systemu były niewiele niższe od kosztów kanalizacji grawitacyjnej. Kanalizacja ciśnieniowa charakteryzowała się najniższymi kosztami inwestycyjnymi, natomiast koszty eksploatacyjne były zbliżone do wartości w kanalizacji podciśnieniowej i jednocześnie prawie dwukrotnie większe niż koszty eksploatacyjne w kanalizacji grawitacyjnej. 
Tabela 1. Zestawienie kosztów inwestycyjnych i eksploatacyjnych

Table 1. Specification of investment and exploitative costs

\begin{tabular}{|c|c|c|}
\hline \multirow{2}{*}{ System } & \multicolumn{2}{|c|}{ Koszty } \\
\cline { 2 - 3 } & $\begin{array}{c}\text { Inwestycyjne } \\
\text { (netto) }\end{array}$ & $\begin{array}{c}\text { Eksploatacyjne } \\
\text { (bez amortyzacji) }\end{array}$ \\
\hline Kanalizacja grawitacyjna & $2601164,48 \mathrm{zł}$ & $59800 \mathrm{zl}$ \\
\hline Kanalizacja ciśnieniowa & $2176038,79 \mathrm{zł}$ & $102344 \mathrm{zl}$ \\
\hline Kanalizacja podciśnieniowa & $2502757,21 \mathrm{zł}$ & $107562 \mathrm{zł}$ \\
\hline
\end{tabular}

\section{Wyniki badań i ich dyskusja}

Obliczone wskaźniki ekonomicznej efektywności inwestycyjnoeksploatacyjnej budowy wybranych systemów kanalizacyjnych wraz z wartościami granicznymi przedstawiono w tabeli 2 .

Tabela 2. Wskaźniki ekonomiczne efektywności inwestycyjno-eksploatacyjnej budowy wybranych systemów kanalizacyjnych

Table 2. Economical indexes of investment and exploitative effectiveness of building selected sewage systems

\begin{tabular}{|c|c|c|c|}
\hline \multirow{2}{*}{$\begin{array}{c}\text { System / } \\
\text { Wartość }\end{array}$} & \multicolumn{3}{|c|}{ Kryterium ekonomiczne } \\
\cline { 2 - 4 } & $D G C$ & $N P V$ & $B C R$ \\
\cline { 2 - 4 } & $\mathrm{zł} / \mathrm{m}^{3}$ & $\mathrm{zł}$ & - \\
\hline Kanalizacja grawitacyjna & 15,32 & $-2555365,76$ & 0,271 \\
\hline Kanalizacja ciśnieniowa & 16,27 & $-2774401,90$ & 0,255 \\
\hline Kanalizacja podciśnieniowa & 18,04 & $-3180126,45$ & 0,230 \\
\hline Wartość graniczna & jak najniższy & $N P V \geq 0$ & $B C R \geq 1$ \\
\hline
\end{tabular}

Pierwszym z wyznaczonych i przeanalizowanych wskaźników był wskaźnik dynamicznego kosztu jednostkowego $(D G C)$, obliczony według zależności (1). W każdym przypadku dynamiczny koszt jednostkowy (DGC) znacznie przewyższał przyjętą wartość opłaty za odprowadzenie $1 \mathrm{~m}^{3}$ ścieków do oczyszczalni $\left(3,19 \mathrm{zz} / \mathrm{m}^{3}\right)$ wraz z opłatą abonamentową, co sugeruje, że żadne z proponowanych rozwiązań nie jest przedsięwzięciem rentownym. Najbardziej nieopłacalna okazała się kanalizacja podciśnieniowa, a najmniej grawitacyjna. Potwierdza to również analiza pozostałych wskaźników dyskontowych. Obliczona według zależności (2) wartość zaktualizowana netto $N P V$ dla wszystkich systemów kanalizacyjnych jest ujemna, co świadczy o nierentowności i nieopłacalności ekonomicznej analizowanej inwestycji. Wskaźnik efektów i nakładów $(B C R)$ obliczony według zależności (3) dla wszystkich rozpatrywanych systemów kanalizacyjnych jest mniejszy od wartości granicznej $(B C R \geq 1)$. Dla poszczególnych systemów kanalizacji wartość $B C R$ jest niższa od granicy opłacalności 
o odpowiednio 72,9\% (kanalizacja grawitacyjna), 74,5\% (kanalizacja ciśnieniowa) i 77\% (kanalizacja podciśnieniowa). Oznacza to, że każda złotówka zainwestowana w rozpatrywane systemy przyniesie odpowiednio 73, 75 i 77 groszy straty.

\section{Podsumowanie}

Ocena efektywności ekonomicznej inwestycji jest ważnym etapem decyzyjnym procesu budowy sieci kanalizacyjnych, pozwala bowiem na określenie jej opłacalności finansowej, z uwzględnieniem nakładów inwestycyjnych i eksploatacyjnych. Często bowiem, jedynym kryterium w wyborze realizacji inwestycji jest koszt inwestycyjny. Dodatkowo, przeprowadzając analizę inwestycyjno-eksploatacyjną budowy systemów wodociągowych lub kanalizacyjnych, należy pamiętać, że budowa kanalizacji sanitarnej określana jest jako tzw. inwestycja „społeczna”, czyli związana np. z poprawą warunków życia czy ochroną środowiska [16].

Finansowa ocena efektywności przedsięwzięcia, z uwzględnieniem nakładów inwestycyjnych i eksploatacyjnych, wykonana ze pomocą wskaźników $D G C, N P V, B C R$ wykazała nieopłacalność budowy sieci kanalizacyjnej w rozpatrywanych wariantach. Wartości wszystkich rozpatrywanych wskaźników dowodzą, że wśród proponowanych rozwiązań, pomimo najwyższych nakładów inwestycyjnych, stosunkowo najkorzystniejsza jest kanalizacja grawitacyjna, niemniej ciągle pozostając przedsięwzięciem nieopłacalnym ekonomicznie. Ewentualna rezygnacja inwestora $\mathrm{z}$ budowy sieci kanalizacji sanitarnej w omawianej miejscowości, powinna zostać poprzedzona kompleksową analizą wielokryterialną. Analiza taka, powinna uwzględniać oprócz ekonomicznego, także kryterium ekologiczne czy niezawodnościowe. Podczas rozpatrywania kryterium ekonomicznego, sugeruje się również określenie możliwości podwyższenia opłaty za usługi kanalizacyjne, co wpływa na rezultaty oceny ekonomicznej efektywności projektowanych inwestycji w zakresie odprowadzania i oczyszczania ścieków. Zalecanym jest również przeanalizowanie alternatywnych do rozpatrywanych rozwiązań projektowych - układów kanalizacji mieszanej lub przydomowych oczyszczalni ścieków.

\section{Literatura}

[1] Blank L.T., Tarquin J.A.: Engineering Economy (3rd Ed.), McGraw-Hill, Singapore 1989.

[2] Błażejewski R.: Kanalizacja wsi, Wyd. Polskie Zrzeszenie Inżynierów i Techników Sanitarnych Oddział Wielkopolski, Poznań 2003.

[3] Boardman A., Greenberg D., Vining A., Weimer D.: Cost-Benefit Analysis: Concepts and Practice, Prentice Hall, Upper Saddle River 1996. 
[4] Budzik-Nowodzińska I., Nowodziński P.: Ocena efektywności inwestycji w odnawialne źródła energii w kontekście uwarunkowań strategicznych: studium przypadku małej elektrowni wodnej, Zeszyty Naukowe Uniwersytetu Szczecińskiego. Finanse. Rynki finansowe. Ubezpieczenia 59/2013, 423-434.

[5] Dolecki J.: Analiza ekonomicznej efektywności układów kanalizacji podciśnieniowej, Ochrona Środowiska, 1984r., Nr 434/3-4, 78-81.

[6] Gostkowska-Drzewiecka T.: Projekty inwestycyjne, ODDK, Gdańsk 1996.

[7] GUS Główny Urząd Statystyczny, Infrastruktura komunalna w 2013 r., Informacje i opracowania statystyczne, Warszawa 2014.

[8] Heidrich Z., Stańko G., Warężak T., Goleń M., Zawadzki A.: Leksykon przydomowych oczyszczalni ścieków. Wydanie II. Poradnik inwestora, Wyd. SeidelPrzywecki, Warszawa 2013.

[9] Kaca E.: Zagrożenia wynikające ze stanu sanitacyjnego wsi, Problemy Inżynierii Rolniczej nr 3/2010, 5-15.

[10] Kalenik M: Hydrauliczne warunki przepływu w rurociągach kanalizacji podciśnieniowej, Wyd. SGGW, Warszawa 2014.

[11] Kalenik M., Siwiec T., Wichowski P.: Kanalizacja ciśnieniowa i podciśnieniowa obszarów wiejskich, Rynek Instalacyjny 11/2012.

[12] Kłos L.: Wpływ infrastruktury technicznej na atrakcyjność obszarów wiejskich, Studia i prace Wydziału Nauk Ekonomicznych i Zarządzania nr 25, Uniwersytet Szczeciński, Szczecin 2012, s. 179-192.

[13] Matz R.: Sieci kanalizacji podciśnieniowej, ciśnieniowej, i grawitacyjnej oraz ich efektywność w danym terenie, Wodociągi-Kanalizacja, Nr 11/2007, s. 194.

[14] Michalski M. Ł.: Analiza metod oceny efektywności inwestycji rzeczowych, Ekonomia Menedżerska 6/2009, 119-128.

[15] Molo M.: Zasady oceny efektywności ekonomicznej przedsięwzięć, ekspertyza przygotowana na zlecenie Urzędu Marszałkowskiego Województwa Małopolskiego, Warszawa 2006.

[16] Noworudzki G.: Metody oceny projektów inwestycyjnych, www.4business4you.com, 2012.

[17] Pearce D., Atkinson G., Mourato S.: Cost-Benefit Analysis and the Environment. Recent Developments, OECD Publishing, Paris 2006.

[18] Prusak B.: Metody oceny projektów inwestycyjnych, Zeszyty Naukowe Politechniki Gdańskiej, Red. Różańska H., Wydawnictwo Politechniki Gdańskiej, Gdańsk 2001, $\mathrm{Nr}$ 573/2001, s. 121-130.

[19] Rączka J.: Analiza efektywności kosztowej w oparciu o wskaźniki dynamicznego kosztu jednostkowego. Transform advice programme - Investment in environmental infrastructure in Poland, Warszawa 2002.

[20] Staroń J.: Analiza ekonomiczna. Program Regionalny Narodowa Strategia Spójności. Województwo Podkarpackie, Rzeszów 2009.

[21] Suligowski Z.: Generowanie kosztów w kanalizacji sanitarnej, Przegląd Komunalny, $\operatorname{Nr} 2 / 2011$.

[22] Szpindor A.: Zaopatrzenie w wodę i kanalizacja wsi, Wyd. Arkady, Warszawa 1998. 
[23] Tarapata Z.: Materiały dydaktyczne - Metody oceny projektów inwestycyjnych, Wojskowa Akademia Techniczna, Warszawa 2003.

[24] Ustawa z dnia 7 czerwca 2001 o zbiorowym zaopatrzeniu wodę i zbiorowym odprowadzaniu ścieków, Dz.U. 2001 nr 72 poz. 747, tekst jednolity.

[25] Widomski M., Iwanek M., Musz A., Ścibior A.: Metody oceny efektywności ekonomicznej inwestycji w projektowaniu gminnej sieci kanalizacji sanitarnej, Polska Inżynieria Środowiska: prace. T. 1, [Red:] Dudzińska Marzenna, Pawłowski Artur Lublin: Politechnika Lubelska, 2012, s 289-298.

\title{
EVALUATION OF ECONOMICAL EFFECTIVNESS OF SELECTED SEWERAGE SYSTEMS
}

\begin{abstract}
S u m m a r y
The sanitation of rural areas is remarkably improving over last few years due to the investment's increase into collective sewerage systems. However, Polish rural areas characterise by lowland terrains and scattered buildings. These conditions do not favour traditional, gravitational sanitary system, what cause a need of implementing unconventional systems. Before an implementation, each investment should be assessed by its economical effectiveness in order to define its financial profitability. Moreover, uneconomical factors, as improving standard of living, should be included in the assessment. To evaluate an investment project, static and dynamic methods are applied. In this paper, an exemplary economic investment-exploitative analysis of selected sewerage systems for rural locality is presented. Gravitational, pressure and vacuum sewage systems were analysed. Localisations of design sewerage pipes were analogical, including special characteristics of each system. Building's connections were ignored as identical in all analysed conceptions. The valuation of economical effectiveness was pursued in accordance to discount (dynamic) methods of a assessing investment project: dynamic generation cost DGC, net present value NPCV, and benefit-cost ratio BCR. Applied factors of project's evaluation included investment's costs and, often ignored, exploitative costs. Basing on pursued analysis, a profitability of each analysed sewerage system was specified, alternative solutions were suggested, and further methods of project assessment were recommended.
\end{abstract}

Keywords: economical analysis, discount methods of project's assessment, sanitary systems, rural areas sanitation

Przestano do redakcji: $30.05 .2015 \mathrm{r}$.

Przyjęto do druku: 30.10.2015 r.

DOI: $10.7862 /$ rb.2015.128 